\title{
Optimal Portfolio of Liquid 45 Stocks: Single Index Model Approach
}

\author{
Abd Muhni Salam 1 , Augustina Kurniasih ${ }^{2}$ \\ 1,2Mercu Buana University Jakarta, Indonesia \\ Email: abdmuhnisalam@yahoo.nl
}

\begin{abstract}
The purpose of this study is to analyze the return, risk, and optimal portfolio performance of LQ45 stocks formed by a single index model in the period August 2017-January 2020. This research is a descriptive study with a quantitative approach. The data collection technique used is documentation study. Based on the results of the calculation, it is found that out of 33 stocks that met the sample criteria, 3 stocks were selected to compile the optimal portfolio, namely BRPT, ICBP, and BBCA stocks. The stock had expected returns of $5.50 \%, 1.34 \%$, and $2.02 \%$, respectively, whit a risk of $12.87 \%, 4.75 \%$, and $4.08 \%$, respectively. The optimal portfolio formed has expected return of $2.60 \%$ and risk of $4.05 \%$. After measuring performance with the Sharpe, Treynor, \& Jensen approach, it is found that the performance of the portfolios that is formed is better than market performance.
\end{abstract}

Keywords: Optimal Portfolio Performance, LQ45, Single Index Model, Optimal Portfolio.

\section{A. INTRODUCTION}

Investment can be interpreted as a commitment to invest a number of funds at this time with the aim of obtaining benefits in the future (Tandelilin, 2017). Investors who invest, both in the capital market and money market, expect returns on their investment (Kurniasih and Johannes, 2015). Investors consider two factors in investing, namely the expected return and the standard deviation (Elton et al., 2014).

Stock exchange is an institution that conducts securities trading. It is in this stock exchange that stocks are bought and sold using the services of securities companies that are members of the stock exchange (Husnan 2015). The Jakarta Composite Index (JCI) or the Jakarta Composite Index (IHSG) is an indicator that shows the movement of the stock prices of all issuers listed on the Indonesia Stock Exchange (IDX). Darmawan \& Purnawati (2015) state that the price of a security generally fluctuates in the direction of the market index.

Prasongko (2019) explains that the flow of stock portfolios is higher in volatility because it is influenced by global economic conditions such as trade wars and the global economic slowdown. Accordingly, the Fiscal Policy Agency (2020) released projections for global economic growth data (\% yoy) and projections for global trade volume growth (\% yoy) as presented in Figure 1 below: 


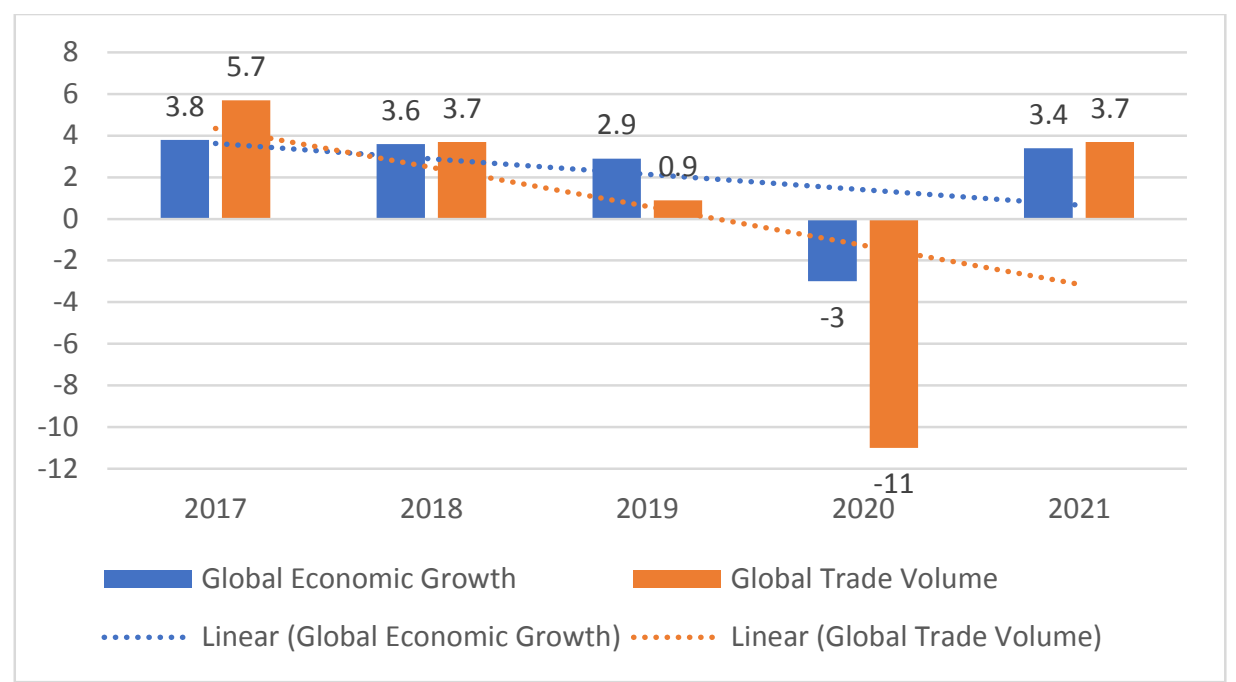

Figure 1. Projections of Economic Growth and Global Trade Volume

Figure 1 shows a decline in global economic growth and a decrease in global trade volume during 2017-2019. This allows an impact on stock trading, so it becomes an interesting phenomenon for researchers to conduct research on stocks. Based on data released on Yahoo Finance, the stock price of the LQ45 index in 20172019 fluctuated from Rp. 908 to Rp1,105 (Figure 2). The more fluctuating the price of a stock, the more risky the stock is. On the other hand, investors basically don't like risk. One way to reduce risk is to diversify. Portfolio formation is a step for investors to diversify. Many stocks that are listed on the exchange often make it necessary for investors to choose good stocks to include in their portfolio. For example Basri (2014) found that Islamic stock prices decreased more than conventional stocks.

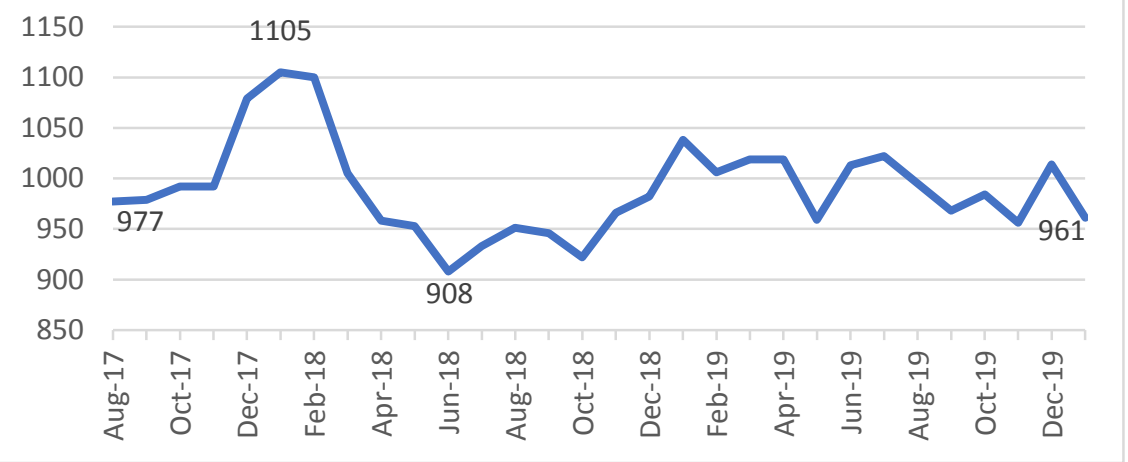

Figure 2. Stock Prices on the LQ45 Index

The Indonesia Stock Exchange (IDX) created an index containing 45 stocks from various companies that have a high level of liquidity, have large market capitalization, good corporate financial conditions and good fundamental conditions. This index is known as the 45 or LQ45 Liquid Index.

A major area of financial research is the positive question "how does one make decisions when faced with risk?" (Elton et al 2014). The problem that often occurs is investors' hesitation in determining stock investment and the large proportion of funds to be invested in these stocks (Pratama, 2019). Investors often experience confusion when selecting securities for their portfolios (Nalini, 2014). 
Portfolio analysis can use various models including the Markowitz model and the single index model. Bekhet and Matar (2012) state that the single index model and the Markowitz model have similarities to the portfolios formed. The Markowitz model emphasizes maximizing expected return and minimizing risk, but it is considered that it involves too much variance and covariance in calculating its portfolio risk (Pratama, 2019). The single index model can simplify calculations on the Markowitz model by providing the input parameters required in the calculation of the Markowitz model (Hartono, 2017). The single index model was chosen because the calculation with the single index model is simpler and can be completed without a special computer program, simply by using Microsoft Excel (Hartono 2017).

The portfolio that has been formed needs to be evaluated for its performance. The evaluation of portfolio performance that is formed is related to two main issues, namely whether the portfolio returns that have been formed are able to provide returns above the benchmark portfolio, and whether the returns obtained are in accordance with the risks borne (Tandelilin, 2017). Portfolio performance measures used to explain these two issues are the Sharpe index, the Treynor index, and the Jensen index.

Various studies in Indonesia regarding the formation of an optimal portfolio with a single index model have been carried out. This research is basically a continuation of previous research. This study updates the observation period for portfolio formation using a single index model for stocks including LQ45 and is consistently included in the index for 5 periods of LQ45 Index assessment, namely from August 2017 to January 2020.

This study aims to find answers to what stocks and what proportion of each are in building an optimal portfolio using a single index model. Also want to know the level of portfolio return and the optimal level of risk using a single index model. Furthermore, the optimal portfolio performance will be analyzed using the Sharpe, Treynor, and Jensen approaches.

\section{B. LITERATURE REVIEW}

The biggest challenge for investors is making decisions under uncertainty. Harry Markowitz in 1952 suggested that one solution to this problem was to suggest that investors invest in different amounts according to their wealth, and invest large amounts in more conservative sectors (Elton et al. 2014).

Markowitz's Portfolio Theory is based on the mean (average) and variance (variant) approach, where the mean is a measure of the rate of return and the variant is a measurement of the level of risk. Markowitz's portfolio theory is also known as the mean-variance model, which emphasizes maximizing the expected return (mean) and minimizing the uncertainty / risk (variant) to select and compile the optimal portfolio. The optimal portfolio is calculated using the following equation (Hartono 2017): 


$$
\begin{gathered}
E\left(R_{p}\right)=\sum_{i=1}^{n} w_{i} \cdot E\left(R_{i}\right) \\
\sigma_{p}^{2}=\sum_{i=1}^{n} w_{i}^{2} \cdot \sigma_{i}^{2}+\sum_{i=1}^{n} \sum_{j=1}^{1} w_{i} \cdot w_{j} \cdot \sigma_{i j}
\end{gathered}
$$

Information:$$
E\left(R_{p}\right)=\text { The expected rate of portfolio return }
$$$$
\mathrm{W}_{\mathrm{i}} \quad=\text { The proportion invested in stock } \mathrm{i}
$$$$
\mathrm{w}_{\mathrm{j}} \quad=\text { The proportion invested in stock } \mathrm{j}
$$$$
\mathrm{E}\left(\mathrm{R}_{\mathrm{i}}\right)=\text { Stock return rate } \mathrm{i}
$$$$
\sigma_{\mathrm{p}}^{2} \quad=\text { Portofolio variance }
$$$$
\sigma_{\mathrm{i}^{2}} \quad=\text { Stock i variance }
$$$$
\sigma_{\mathrm{ij}} \quad=\text { Standard deviasi of stocks } \mathrm{i} \text { and } \mathrm{j}
$$

The single index model illustrates that all stocks are affected by general market movements. As the market improves, the prices of individual stocks will also increase. This is indicated by the available market index. Conversely, if the market condition worsens, a decline in stock prices will follow. The single index model uses a market index to proxy for common factors (Bodie et al. 2011). This gives the reason that the returns of securities are correlated because of the same response to market changes, and the measurement of this correlation is done by connecting the returns of a stock with the returns from the stock market index. This shows that the stock return rate is formulated as follows (Husnan, 2015):

$$
R_{i}=a_{i}+\beta_{i} R_{m}
$$

Information:

$\mathrm{R}_{\mathrm{i}} \quad=$ Stock return $\mathrm{i}$

$\mathrm{a}_{\mathrm{i}} \quad=$ The component of stock return $\mathrm{i}$ that is not affected by changes in the market index

$\beta_{\mathrm{i}} \quad=$ A constant that measures the change in $\mathrm{R}_{\mathrm{i}}$ due to the change in $\mathrm{R}_{\mathrm{m}}$

$\mathrm{R}_{\mathrm{m}} \quad=$ Market returns

The optimal portfolio formation is carried out using the cut-off rate method on a single index model (Elton et al. 2014) with the following steps:

1. Sort the stocks based on the value of the excess return to beta ratio from the largest to the smallest obtained from the equation:

Information:

$$
E R B_{i}=\frac{E\left(R_{i}\right)-R_{f}}{\beta_{i}}
$$

$$
\begin{array}{ll}
\mathrm{ERB}_{\mathrm{i}} & =\text { Excess return to stock beta } \mathrm{i} \\
\mathrm{R}_{\mathrm{f}} & =\text { Risk free of return } \\
\beta_{\mathrm{i}} & =\text { Stock beta } \mathrm{i}
\end{array}
$$


2. Calculate the candidate cut-off rate $(\mathrm{Ci})$ obtained from the following equation:

Information:

$$
C_{i}=\frac{\sigma_{m}^{2} \sum_{i=0}^{n} \frac{\left[E\left(R_{i}\right)-R_{f}\right] \beta_{i}}{\sigma_{e i}{ }^{2}}}{1+\sigma_{m}^{2} \sum_{i=0}^{n}\left[\frac{\beta_{i}^{2}}{\sigma_{e i}{ }^{2}}\right]}
$$

$\mathrm{Ci}=$ Candidate cut-off rate

$\sigma \mathrm{m} 2=$ Market variance

$\mathrm{E}(\mathrm{Ri})=$ Expected rate of return

бei2 = Unique variance

3. Determine the cut-off point value $\left(C^{*}\right)$, namely the last $\mathrm{Ci}$ value in the ranking order of the stocks above that have an excess return to beta ratio value greater than $\mathrm{Ci}$. Stocks with excess return to beta ratio above $\mathrm{Ci}$ are selected stocks which are then used to find the weight of each stock in forming an optimal portfolio.

4. Determine the weight of each stock in the portfolio through the following equation:

$$
\begin{gathered}
Z_{i}=\frac{\beta_{i}}{{\sigma_{e i}{ }^{2}}^{2}} E R B_{i} \\
X_{i}=\frac{Z_{i}}{\sum_{i=1}^{n} Z_{i}}
\end{gathered}
$$

Information:

$\mathrm{Xi} \quad=$ Percentage of stock investment weight $\mathrm{i}$

$\mathrm{Zi} \quad=$ Equity investment fund allocation weight $\mathrm{i}$

$\mathrm{C}^{*} \quad=$ Cut-off point

The advantage of the single index model lies in the simplification of the optimal portfolio formation process without reducing the accuracy of the portfolio performance that is formed. The process of forming an optimal portfolio using this method can even be done with simple calculations according to the equations used at each step.

Furthermore, portfolio performance is measured by 3 models, namely Sharpe Ratio, Treynor Ratio, and Jensen Alpha Ratio. The sharpe ratio is done by dividing the excess return by the portfolio standard deviation (Bodie et al. 2011). Treynor ratio is done by dividing the excess return by the systematic risk (Bodie et al. 2011). Jensen Alpha Ratio is the difference between the average portfolio and the value according to CAPM (Hartono, 2017).

The framework of this research is presented in Figure 3. 


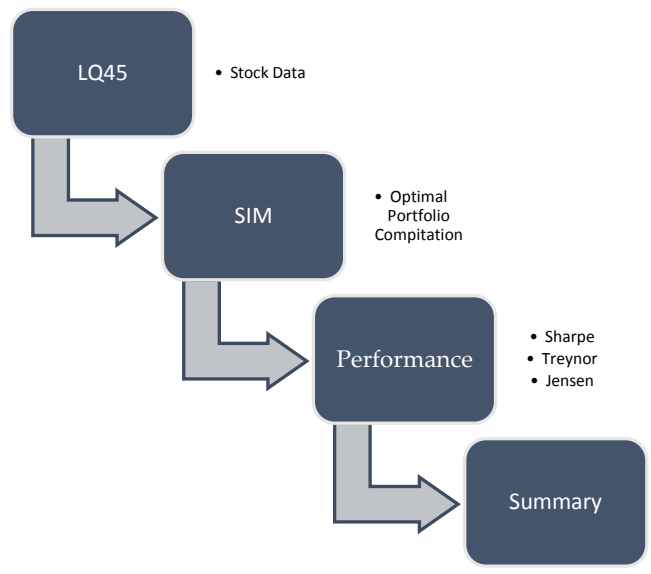

Figure 3. Research Framework

\section{METHOD}

This research is a descriptive study with a quantitative approach. This study uses a population of company stocks on the IDX which are classified as LQ45 stocks. From this population, several samples were taken using purposive sampling technique, namely those that met the criteria including the LQ45 stock group for successively in the period August 2017 to January 2020.

Data collection was carried out by means of documentation. This technique is done by collecting data from books, previous research, reports published by Bank Indonesia and the Indonesia Stock Exchange.

The data used are secondary data and ratio scale. To answer this research problem, it requires monthly data regarding the BI Rate (http://www.bi.go.id), a list of stocks included in the LQ45 index (http://www.idx.co.id), and data adjective close stock price and composite stock price index / IHSG (https://finance.yahoo.com).

Data analysis was performed by calculating a single index model to determine an efficient portfolio set. Data processing uses Microsoft Excel and IBM SPSS Statistics 23. Data processing steps are as follows:

1. Calculating realized return, expected return, standard deviation, and variance of each individual stock by referring to the IHSG and BI Rate.

a. Realized Return (Hartono, 2017)

$$
R_{i}=\frac{P_{t}-P_{t-1}}{P_{t-1}}
$$

b. Expected Return (Hartono, 2014)

$$
E\left(R_{i}\right)=\frac{\sum_{i=1}^{n} R_{i}}{n}
$$


c. Standard Deviation (Hartono, 2017)

$$
\sigma_{i}=\sqrt{\frac{\sum_{t=1}^{n}\left[R_{i t}-E\left(R_{i}\right)\right]^{2}}{n}}
$$

2. Calculate beta, alpha and the unique risk of each stock using the following equation.

a. Beta (Hartono, 2017)

$$
\beta_{i}=\frac{\sigma_{i M}}{\sigma^{2}{ }_{M}}=\frac{\sum_{t=1}^{n}\left(R_{i}-E\left(R_{i}\right)\right) \cdot\left(R_{M}-E\left(R_{M}\right)\right)}{\sum_{t=1}^{n}\left(R_{i}-E\left(R_{i}\right)\right)^{2}}
$$

b. Alpha (Hartono, 2014)

$$
\alpha_{i}=E\left(R_{i}\right)-\left(\beta_{i} \cdot E\left(R_{M}\right)\right)
$$

c. Unique risk (Hartono, 2017)

$$
\sigma_{e i}^{2}=\sigma_{i}^{2}-\left(\beta_{i}^{2} \cdot \sigma_{M}^{2}\right)
$$

3. Risk Free Rate of Return (Rf) uses the average monthly BI rate for 30 months, namely the period August 2017-January 2019.

4. Calculating the excess return to beta (ERB) value and the Ci value of each stock.

a. ERB (Hartono, 2017)

$$
E R B=\frac{E\left(R_{i}\right)-R f}{\beta_{i}}
$$

b. $\mathrm{C}_{\mathrm{i}}$ (Hartono, 2014)

$$
C_{i}=\frac{\sigma_{M}^{2} \sum_{j-1}^{i} A_{j}}{1+\sigma_{M}^{2} \sum_{j-1}^{i} B_{j}}
$$

Where

$$
\begin{gathered}
A_{i}=\frac{\left[E\left(R_{i}\right)-R_{f}\right] \cdot \beta_{i}}{\sigma_{e i i^{2}}} \\
B_{i}=\frac{{\beta_{i}{ }^{2}}_{\sigma_{e i}{ }^{2}}}{}
\end{gathered}
$$

5. Determine the cut-off point $\left(\mathrm{C}^{*}\right)$. The cut-off point $\left(\mathrm{C}^{*}\right)$ is the maximum $\mathrm{Ci}$ value of a series of stock $\mathrm{Ci}$ values.

6. Looking for stocks that have an ERB value $>C^{*}$ to be used as a portfolio.

7. Determine the weight of the stocks to be invested in the optimal portfolio, with the following equation (Hartono, 2014).

$$
\begin{gathered}
Z_{i}=\frac{\beta_{i}}{\sigma_{e i}{ }^{2}}\left(E R B_{i}-C^{*}\right) \\
w_{i}=\frac{Z_{i}}{\sum_{j=1}^{k} Z_{j}}
\end{gathered}
$$

8. Calculate alpha, beta, systematic risk, unique risk, total risk, and portfolio expected return. 
9. Calculating and testing different portfolio performance using the Sharpe, Treynor, and Jensen methods.

\section{RESULT AND DISCUSSION}

Stocks in the LQ45 Index are the object of this study. LQ45 was first formed on February 24, 1997, consisting of 45 liquid stocks that are actively traded. The selection of stocks included in this index is carried out with strict and highly selective criteria. The LQ45 index is intended as a complement to the JCI and specifically as an objective and reliable tool for conducting financial analysis and monitoring the movements of actively traded stocks. As long as it was formed until the last period, namely August 2020-January 2021, there were stocks with high liquidity that constantly flitted out and entered the LQ45 list. The companies on the list are companies listed on the IDX, both government and private companies.

\section{Analysis of Stocks in LQ45 Index and Their Proportions in Building an Optimal Portfolio}

There are 60 stocks listed as LQ45 Index during the period August 2017January 2020. These stocks are in the top 60 and in the top 95\% of the total average annual value of stock transactions on the regular market, in the top $90 \%$ position of the average annual market capitalization, and is the highest order that represents its sector in the IDX industry classification and is the highest order based on the frequency of transactions. Out ff the 60 stocks, there are 33 consistent stocks in LQ45 Index.

The stock price obtained from Yahoo Finance becomes data to determine the realized return of each stock. This is done because stock prices reflect firm value (Kurniasih, et al, 2011). The return (rate of return) obtained is positive or negative. This value shows the increase and decrease in stock returns.

The JCI data is used as the basis for the realization of market returns because the JCI reflects an indicator that shows the overall price movements of stocks listed on the Indonesia Stock Exchange (Sari and Nuzula, 2017). The calculation results show that market realized returns also experience positive and negative values. This means that the JCI is also moving up and down.

Table 1 shows the results of calculating realized return, expected return, standard deviation, beta, alpha, unique risk, ERB, cut off rate, and C* of 33 LQ45 stocks that meet the sample criteria and market index (IHSG). It can be seen that consistent stocks come from 8 industrial sectors on the IDX, except the agricultural sector. There are 13 stocks are BUMN and 20 others are private companies. The calculation results show that the largest expected return is BRPT (0.0550). The smallest expected return is LPPF (-0.0321). This shows that there are differences in the financial conditions of each company during the 30 months of the study period.

The stocks with the lowest risk with a positive expected return are shown by BBCA. This stock is a stock of the financial sector and is known for its large capitalization and very strong fundamentals. Apart from BBCA, from the financial 
sector there are 2 state-owned banks namely BMRI and BBRI which have a positive expected return with the lowest risk position of 5. ICBP from the consumer goods industry sector also have a positive expected return with low risk.

Individual stock beta becomes a systematic risk measure which is a coefficient that describes changes in individual stock returns (Ri) as a result of changes in market returns / JCI (RM). Beta is an indicator of how much risk a stock is, and is used to evaluate its expected return. The smallest beta value is indicated by TLKM stock (0.1383). A positive beta value indicates that TLKM are moving in the direction of the market.

The results of the calculation of all the stocks studied showed the largest alpha value in BRPT, namely 0.0542, while the lowest was in LPPF (-0.0338). BRPT can become stock that strengthen equity mutual funds by including them in its portfolio. In 2019, BRPT price increased to $215.90 \%$ year to date from IDR 478 , - on January 1, 2019 to IDR 1,510, - on December 30, 2019. LPPF with the lowest alpha also occurred in the research of Maghdalena et al. (2020). It means that LPPF is not the first time it has had the lowest alpha among the LQ45. Generally, investors will choose stocks with large alpha values. The greater the alpha, the greater the stock beats the market index, so that it is considered to represent the value that increases or decreases stock returns.

Table 1. LQ45 Stock Indicator for the Period August 2017-January 2019

\begin{tabular}{|c|c|c|c|c|c|c|c|c|c|c|c|}
\hline \multirow{2}{*}{$\begin{array}{l}\text { Stock } \\
\text { Code }\end{array}$} & \multicolumn{2}{|c|}{ Realized Return } & \multirow{2}{*}{$E(R i)$} & \multirow{2}{*}{$\sigma \mathrm{i}$} & \multirow{2}{*}{$\beta \mathrm{i}$} & \multirow{2}{*}{$\alpha \mathrm{i}$} & \multirow{2}{*}{$\sigma \varepsilon \dot{i}^{2}$} & \multirow{2}{*}{ ERBi } & \multirow{2}{*}{$\mathrm{Ci}$} & \multirow{2}{*}{$C^{*}$} & \multirow{2}{*}{ Inf. } \\
\hline & Min & Max & & & & & & & & & \\
\hline BRPT & $-0,2211$ & 0,3175 & $-0,0003$ & 0,1287 & 0,7177 & 0,0542 & 0,0161 & 0,0706 & 0,00209 & & Optimal \\
\hline ICBP & $-0,1621$ & 0,2239 & $-0,0159$ & 0,0475 & 0,3562 & 0,0131 & 0,0021 & 0,0256 & 0,00331 & & Optimal \\
\hline BBCA & $-0,1962$ & 0,4630 & 0,0114 & 0,0408 & 0,9887 & 0,0192 & 0,0007 & 0,0161 & 0,01020 & $\begin{array}{l}\text { Ma } \\
\mathrm{x}\end{array}$ & Optimal \\
\hline BBRI & $-0,1538$ & 0,0841 & $-0,0039$ & 0,0535 & 1,2935 & 0,0161 & 0,0013 & 0,0101 & 0,01017 & & \\
\hline INCO & $-0,0540$ & 0,1015 & 0,0202 & 0,1387 & 2,5483 & 0,0157 & 0,0131 & 0,0055 & 0,00963 & & \\
\hline SMGR & $-0,1682$ & 0,2223 & 0,0037 & 0,1111 & 2,2143 & 0,0108 & 0,0077 & 0,0040 & 0,00890 & & \\
\hline BMRI & $-0,0783$ & 0,1493 & 0,0174 & 0,0439 & 0,8070 & 0,0063 & 0,0013 & 0,0035 & 0,00840 & & \\
\hline ANTM & $-0,1968$ & 0,2595 & $-0,0033$ & 0,1466 & 2,4961 & 0,0088 & 0,0156 & 0,0028 & 0,00802 & & \\
\hline $\begin{array}{c}\text { MNC } \\
\mathrm{N}\end{array}$ & $-0,0909$ & 0,1005 & 0,0071 & 0,1527 & 1,5535 & 0,0063 & 0,0210 & 0,0024 & 0,00791 & & \\
\hline PTBA & $-0,1811$ & 0,4316 & 0,0550 & 0,1182 & 1,4079 & 0,0057 & 0,0121 & 0,0020 & 0,00775 & & \\
\hline INTP & $-0,1374$ & 0,2273 & $-0,0127$ & 0,1185 & 2,1490 & 0,0052 & 0,0097 & 0,0015 & 0,00730 & & \\
\hline WIKA & $-0,2212$ & 0,2002 & 0,0000 & 0,1430 & 2,7395 & 0,0047 & 0,0133 & 0,0012 & 0,00682 & & \\
\hline BBNI & $-0,2461$ & 0,1612 & $-0,0047$ & 0,0798 & 1,8632 & 0,0018 & 0,0031 & $-0,0003$ & 0,00585 & & \\
\hline PGAS & $-0,1743$ & 0,1534 & $-0,0129$ & 0,1468 & 2,4377 & $-0,0004$ & 0,0159 & $-0,0009$ & 0,00555 & & \\
\hline ADRO & $-0,0880$ & 0,1262 & 0,0134 & 0,1147 & 2,0363 & $-0,0025$ & 0,0092 & $-0,0023$ & 0,00517 & & \\
\hline INDF & $-0,2129$ & 0,2976 & 0,0184 & 0,0601 & 0,7489 & 0,0011 & 0,0031 & $-0,0033$ & 0,00500 & & \\
\hline PTPP & $-0,1067$ & 0,1288 & 0,0019 & 0,1577 & 3,7012 & $-0,0163$ & 0,0118 & $-0,0045$ & 0,00395 & & \\
\hline WSKT & $-0,2719$ & 0,2549 & 0,0075 & 0,1296 & 3,1824 & $-0,0147$ & 0,0072 & $-0,0049$ & 0,00289 & & \\
\hline BBTN & $-0,1440$ & 0,1606 & $-0,0044$ & 0,1127 & 1,4374 & $-0,0048$ & 0,0107 & $-0,0053$ & 0,00276 & & \\
\hline KLBF & $-0,1177$ & 0,1498 & $-0,0033$ & 0,0606 & 1,1828 & $-0,0046$ & 0,0023 & $-0,0065$ & 0,00232 & & \\
\hline JSMR & $-0,3017$ & 0,2499 & $-0,0321$ & 0,0762 & 1,3190 & $-0,0058$ & 0,0042 & $-0,0066$ & 0,00204 & & \\
\hline SCMA & $-0,2337$ & 0,3415 & 0,0080 & 0,0965 & 1,8450 & $-0,0108$ & 0,0061 & $-0,0072$ & 0,00166 & & \\
\hline GGRM & $-0,2569$ & 0,4918 & 0,0021 & 0,0782 & 1,1632 & $-0,0059$ & 0,0048 & $-0,0078$ & 0,00147 & & \\
\hline ASII & $-0,1692$ & 0,3823 & 0,0072 & 0,0552 & 1,0290 & $-0,0050$ & 0,0020 & $-0,0080$ & 0,00113 & & \\
\hline UNVR & $-0,2393$ & 0,3950 & $-0,0125$ & 0,0568 & 0,9530 & $-0,0044$ & 0,0024 & $-0,0081$ & 0,00089 & & \\
\hline
\end{tabular}




\begin{tabular}{|c|c|c|c|c|c|c|c|c|c|c|c|}
\hline AKRA & $-0,2034$ & 0,2200 & $-0,0089$ & 0,0982 & 2,1061 & $-0,0181$ & 0,0054 & $-0,0096$ & 0,00034 & & \\
\hline EXCL & $-0,1517$ & 0,3361 & 0,0131 & 0,0977 & 0,4382 & $-0,0005$ & 0,0094 & $-0,0099$ & 0,00033 & & \\
\hline HMSP & $-0,1550$ & 0,0932 & $-0,0112$ & 0,0726 & 1,5129 & $-0,0145$ & 0,0031 & $-0,0114$ & $-0,00020$ & & \\
\hline BSDE & $-0,1390$ & 0,0762 & $-0,0047$ & 0,0776 & 1,2832 & $-0,0141$ & 0,0045 & $-0,0133$ & $-0,00049$ & & \\
\hline UNTR & $-0,1791$ & 0,1155 & $-0,0088$ & 0,0794 & 0,8591 & $-0,0096$ & 0,0056 & $-0,0152$ & $-0,00061$ & & \\
\hline LPPF & $-0,0812$ & 0,1339 & $-0,0034$ & 0,1448 & 1,6162 & $-0,0338$ & 0,0185 & $-0,0226$ & $-0,00079$ & & \\
\hline SRIL & $-0,2066$ & 0,3686 & 0,0076 & 0,0576 & 0,5209 & $-0,0117$ & 0,0031 & $-0,0297$ & $-0,00094$ & & \\
\hline TLKM & $-0,2120$ & 0,2805 & $-0,0114$ & 0,0545 & 0,1383 & $-0,0049$ & 0,0030 & $-0,0653$ & $-0,00096$ & & \\
\hline IHSG & $-0,0620$ & 0,0677 & 0,0010 & & & & & & & & \\
\hline
\end{tabular}

The unique risks of stocks are risks that can be avoided by diversifying. Unique risk $\left(\sigma_{e i}{ }^{2}\right)$ is calculated from the variance of the stock $\left(\sigma_{e i}{ }^{2}\right)$ minus $\beta_{i}{ }^{2}$ multiplied by the market variance. The unique risk of BBCA's 0.0007 stock is due to the company's strong internal fundamentals. According to Melani (2019) BBCA has the highest market capitalization on the IDX and in 2019 reached the highest stock price in the last 10 years. MNCN have a unique risk with a value of 0.0210 , which is the highest among other stocks. According to Caesario (2019) in the fourth quarter of 2018, MNCN content revenue performance decreased by $4 \%$, non-core revenue throughout 2018 fell 44\%, and the program cost component increased 6\% yoy from 2017 to 2018. Although the effect was micro, this condition still needs to be considered by investors.

Excess return to beta (ERB) is the excess of stock returns on risk free asset returns (Bangun et al 2012). The data above shows that the stocks of BRPT, ICBP, BBCA, BBRI, and INCO are the 5 stocks with the largest ERB.

The stock boundary point is denoted by $\mathrm{C}^{*}$, which is the largest $\mathrm{Ci}$ value for all candidates for the optimal portfolio composition. Candidates compiling the optimal portfolio must have an ERB value $>\mathrm{Ci}$. If the ERB value is greater or equal to 0.0161 , candidate stocks are included as an optimal portfolio compiler. There are 3 (three) stocks that meet this criteria, namely BRPT (0.0706), ICBP (0.0256), and BBCA (0.0161). Singh and Gautam's research (2014) shows that of the 10 companies studied, only 2 companies were selected for investment purposes.

Determination of the weight $\left(\mathrm{W}_{\mathrm{i}}\right)$ of the optimal portfolio compilers is based on the weighted scale $\left(\mathrm{Z}_{\mathrm{i}}\right)$ of each stock. Table 2 shows the highest weight is BBCA $(60.14 \%)$.

Table 2. Optimal Portfolio Compiler Stocks Weight

\begin{tabular}{|c|c|c|}
\hline Stock & $\mathrm{Zi}$ & Wi \\
\hline BRPT & 2,6959 & 0,2037 \\
\hline ICBP & 2,5788 & 0,1949 \\
\hline BBCA & 7,9567 & 0,6013 \\
\hline Amount & 13,2314 & 1,0000 \\
\hline
\end{tabular}

Oktafiani, et al. (2017) found a similar thing that BBCA have the largest proportion (63.82\%) in a portfolio consisting of 6 stocks. According to Nalini (2014) 
the final investment decision must be made after considering all the factors that affect stocks.

\section{Optimal Portfolio Return Rate Analysis}

Realized return of individual stocks compiling the optimal portfolio that has been averaged to produce the expected return using the mean method. It has been found that the expected return of 3 stocks that make up the optimal portfolio, namely BRPT, BBCA, ICBP, is $5.50 \%, 2.02 \%$ and $1.34 \%$, respectively. The three stocks come from different sectors. BRPT is a diversified and integrated natural resource company that is included in the Basic Industry and Chemical Sector. BBCA is a banking company that is part of the Financial or Financial Sector. ICBP is a company engaged in the food product industry so that it is included in the Consumer Goods Industry sector. Different sectors become one of the bases for diversification in preparing a portfolio in order to minimize risk.

The expected return on stocks obtained based on the average method can be an initial picture for investors to see the potential return in the future. However, it is necessary to pay attention to the expected market return, which is $0.1 \%$. It can be concluded that the expected return of the portfolio compilers is far above the market. Portfolio arrangement causes the spread of returns or reduces high returns and raises low returns. Through an optimal portfolio, investors want maximum returns with minimum risk (Poornima and Remesh, 2015).

The portfolio expected return is obtained by adding up all the results of the multiplication between the stock weight and the individual stock returns. The value of the expected portfolio return, portfolio beta, and unique portfolio risk is presented in Table 3.

Table 3. Portfolio Expected Return Value, Portfolio Beta, and Unique Portfolio Risk

\begin{tabular}{|c|c|c|c|}
\hline Stock Code & $\mathrm{W}_{\mathrm{i}} \cdot \mathrm{E}\left(\mathrm{R}_{\mathrm{i}}\right)=\mathrm{E}\left(\mathrm{R}_{\mathrm{p}}\right)$ & $\mathrm{W}_{\mathrm{i}} \cdot \beta_{\mathrm{i}=} \beta_{\mathrm{p}}$ & $\mathrm{W}_{\mathrm{i}}{ }^{2} \cdot \sigma_{\mathrm{ei}}{ }^{2}=\sigma_{\mathrm{ep}}{ }^{2}$ \\
\hline BRPT & 0,0112 & 0,1462 & 0,00067 \\
\hline ICBP & 0,0026 & 0,0694 & 0,00008 \\
\hline BBCA & 0,0122 & 0,5946 & 0,00025 \\
\hline & 0,0260 & 0,8102 & 0,00100 \\
\hline
\end{tabular}

The portfolio's expected return is smaller than the expected return on BRPT's stock, but greater than the ICBP and BBCA stocks. This is one of the characteristics of diversification that can share risk and return. The formed portfolio's expected return is $2.6 \%$ per month or $31.2 \%$ per year. This value is greater than the average risk free rate (Rf) during the study period, namely $0.43 \%$ per month or $5.16 \%$ per year.

Large returns are accompanied by large risks. The return and risk relationship is the basis for making investment decisions. Investors expect high expected returns according to the investor's ability to bear the risks that may occur. 
Aliakur \& Triaryati's (2017) research results regarding the formation of portfolios with a single index model show that the JCI is under pressure due to the increase in the interest rate of the American Central Bank at the end of 2015, so that portfolio returns get negative results.

Differences in market conditions and different research methods may produce different findings. Witiastuti (2012) found that the expected return results differ significantly between those calculated using the single index method versus the naive diversification method.

\section{Optimal Portfolio Risk Level Analysis}

The risk of individual stocks compiling the optimal portfolio, namely BRPT, ICBP, and BBCA, is $12.87 \%, 4.75 \%$ and $4.08 \%$, respectively. This risk consists of systematic risk and unsystematic risk. This systematic risk is influenced by the market, while unsystematic risk is not influenced by the market.

The systematic risk for BRPT, ICBP, and BBCA are $0.05 \%, 0.01 \%$, and $0.09 \%$, respectively. This systematic risk cannot be reduced because it is attached to the fundamentals and the market, so this risk must be borne by investors. Unsystematic risk can be reduced through diversification or portfolio creation by combining several stocks in one investment period.

The unsystematic risk of BRPT, ICBP, and BBCA are $1.61 \%, 0.21 \%$, and $0.07 \%$, respectively. This unsystematic risk can be reduced or minimized through portfolio compilation. Market risk is 3.08\% lower than the total risk of the three portfolio constituent stocks. This condition further supports the need to form a portfolio to reduce investment risk.

The total portfolio risk based on the beta value of the portfolio, market variants, and unique variants of the portfolio results in the total risk of the portfolios formed of $4.05 \%$. Portfolio risk is proven to reduce the risk of individual stocks, but is higher than market risk. The consequence is that the return is lower than individual stocks, but higher than the market return. This doesn't just apply to stocks of LQ45 Index. The IDX30 portfolio also experienced the same thing (Wahyuni and Darmayanti, 2019). It is stated that by forming an investor's portfolio can reduce his risk from the total risk of investing in a single security. For that investors need to monitor the market continuously and update the selected stocks for the right investment (Poornima and Remesh, 2016).

\section{Optimal Portfolio Performance Analysis}

The optimal portfolio performance formed is analyzed using Sharpe, Treynor, and Jensen measurements. Sharpe measurement is done by dividing excess return by portfolio risk. Obtained a portfolio performance value of 0.5358 . The market performance (JCI) resulted in a value of -0.1061 . It can be concluded that based on the Sharpe performance measurement, the formed portfolio is better than market performance. Figure 3 shows a graph of the risk and return positions for the single 
index model portfolio that is formed, the risk free rate, and market conditions in the monthly period.

Figure 3 shows that the market return (IHSG) is below the Rf and with a high risk. The condition of the capital market is influenced by many factors, both domestic and foreign.

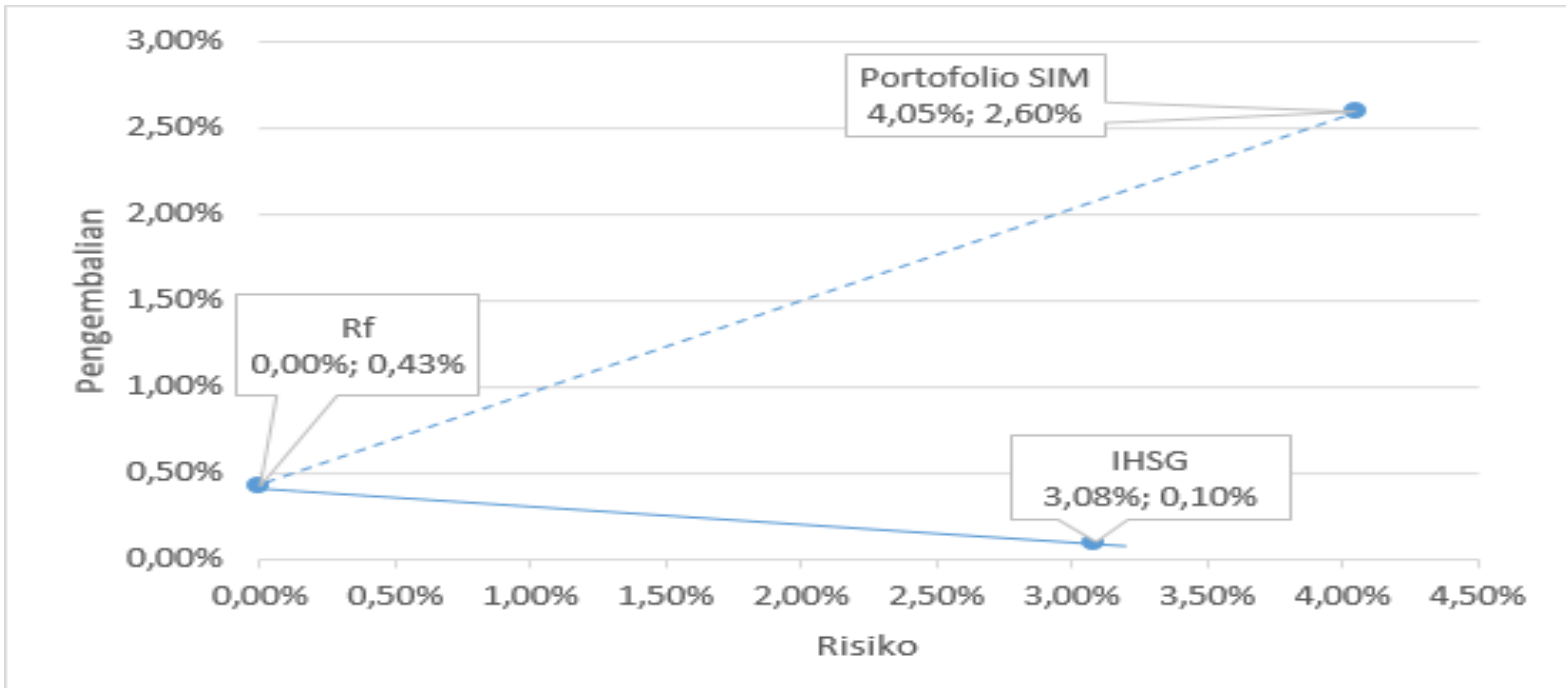

Figure 4. Rf, IHSG, and Portfolios Formed by Sharpe Measurement

The formed portfolio provides an overview of what investments can be made. Saleh (2020) stated that ICBP were still one of the best stocks when the JCI was weak. This condition also occurred in this study.

Portfolio performance is also measured using the Treynor measurement. This measurement is done by dividing the excess return by the portfolio beta. Beta measures the sensitivity of a portfolio to market movements. Obtained portfolio performance value is 0.0268 and JCI -0.0033 . Based on the Treynor approach, the performance of a portfolio that is formed is better than the market.

Furthermore, portfolio performance is also analyzed using Jensen's measurement. If Sharpe and Treynor's approximation measures the angle or slope, Jensen's measurement is against the intercept. Based on Jensen's portfolio performance is 0.0244 . These results indicate a positive value, namely the value of the intersection on the vertical axis which is above the zero point. The zero point is the JCI. Thus it can be concluded that the portfolio formed with 3 stocks (BRPT, ICBP, and BBCA) has a good performance and is above the market.

Based on the 3 approaches to measuring portfolio performance, tests are conducted to prove whether there are differences between the three approaches. Because the resulting research data was not normally distributed, the MannWhitney $U$ difference test was used. The test results showed that the Sharpe approach portfolio performance measurement was significantly different from the Treynor \& Jensen approach. There is no significant difference between Treynor \& Jensen's approach. This finding is different from the research of Ong et al. (2012) 
who found similarities in the measurement results of Sharpe \& Treynor but different from Jensen's.

\section{E. CONCLUSION}

The formation of the optimal portfolio of LQ45 stocks on the Indonesia Stock Exchange using a single index model in the period August 2017 to January 2020 resulted in the following conclusions: (1) there are 3 stocks forming the optimal portfolio, namely BRPT (Barito Pacific Tbk.), ICBP (Indofood CBP Sukses Makmur Tbk.) and BBCA (Bank Central Asia Tbk.) with the proportion of $20.37 \%, 19.49 \%$ and $60.14 \%$, respectively; (2) The optimal portfolio return is 0.0260 or $2.60 \%$; (3) The optimal portfolio risk is 0.0405 or $4.05 \%$; and (4) The optimal portfolio performance based on Sharpe measurement is 0.5358, Treynor 0.0268, Jensen is 0.0244. All performance measurements are positive, which indicates that the portfolios are performing well.

\section{REFERENCES}

1. Aliakur, G. Jr., \& Triaryati, N. (2017). Kinerja Portofolio Optimal Berdasarkan Model Indeks Tunggal. E-Jurnal Manajemen Unud, 6(5), 2528-2555.

2. Badan Kebijakan Fiskal. (2020). Tinjauan Ekonomi, Keuangan, E Fiskal. Retrieved from www.fiskal.kemenkeu.go.id

3. Bangun, D. H., Anantadjaya, S. P. D., \& Lahindah, L. (2012). Portofolio Optimal menurut Markowitz Model dan Single Index Model: Studi Kasus pada Indeks LQ45. JAMS - Journal of Management Studies, 1(1), 70-93.

4. Basri (2014). Perbandingan Kinerja Saham Syariah dan Saham Konvensional di Bursa Efek Indonesia (Studi Kasus Tahun 2013). Jurnal Bisnis dan Ekonomi, 5(2), 127-147.

5. Bekhet, H. A., \& Matar, A. (2012). Risk-Adjusted Performance: A two- model Approach Application in Amman Stock Exchange. International Journal of Business and Social Science, 3(7), 34-45.

6. Bodie, Z., Kane, A., \& Marcus, A. J. (2011) Investments. New York: McGrawHill/Irwin.

7. Caesario, E. B. (2019) Kinerja 2018: Media Nusantara Citra (MNCN) Bukukan Pertumbuhan Pendapatan 6 Persen. Retrieved from https://market.bisnis.com/read/20190227/192/893979/kinerja-2018-medianusantara-citra-mncn-bukukan-pertumbuhan-pendapatan-6-persen.

8. Darmawan, I P. P. A., \& Purnawati, N. K. (2015). Pembentukan Portofolio Optimal pada Saham-Saham di Indeks LQ45 dengan Menggunakan Model Indeks Tunggal. E-Jurnal Manajemen Unud, 4(12), 4335-4361.

9. Elton, E. J., Gruber, M. J., Brown, S. J., \& Goetzmann, W. N. (2014) Modern Portfolio Theory and Investment Analysis. New York: Wiley. 
10. Hartono, J. (2014). Teori dan Praktik Portofolio dengan Excel. Jakarta: Salemba Empat.

11. Hartono, J. (2017). Teori Portofolio dan Analisis Investasi. Yogyakarta: BPFE.

12. Husnan, S. (2015). Dasar-Dasar Teori Portofolio dan Analisis Sekuritas. Yogyakarta: UPP STIM TKPN.

13. Kurniasih, A., \& Johannes, L. D. Y. (2015) Analisis Variabel Makroekonomi terhadap Kinerja Reksadana Campuran, Jurnal Manajemen, 19(1), 136-151.

14. Kurniasih, A., Siregar, H., Sembel, R., \& Achsani, N. A. (2011). Market Reaction to the Cash Dividend Announcement: An Empirical Study from Indonesia Stock Exchange 2004-2009. European Journal of Economic, Finance and Administrative Science, (40), 92-100.

15. Magdalena, R. M., Mulyantini, S., \& Nurmantias. (2020). Analisis Pembentukan Portofolio Optimal untuk Keputusan Inveestasi pada Saham LQ45 dan JII. Konferensi Riset Nasional Ekonomi, Manajemen, dan Akuntansi. Retrieved from http://ocs.upnvj.ac.id/index.php/korelasi/2020/paper/view/989.

16. Melani, A. (2019). Melihat Laju Saham BCA Selama 2009-2019. Retrieved from https://www.liputan6.com/bisnis/read/3878803/melihat-laju-saham-bca-selama2009-2019.

17. Nalini, R. (2014). Optimal Portofolio Construction Using Sharpe's Single Index Model-A Study of Selected Stocks from BSE. International Journal of Advanced Research in Management and Social Sciences, 3(12), 72-93.

18. Oktafiani, H. E., Maruddani, D. A. I, \& Suparti. (2017). Penerapan Model Indeks Tunggal untuk Optimalisasi Portofolio dan Pengukuran Value at Risk dengan Variance Covariance. Jurnal Gaussian, 6(1), 41-50.

19. Ong, T. S., Teh, B. H., Soh, C. H., \& Yan, Y. L. (2012). Malaysian Real Estate Investment Trust: A Performance and Comparative Analysis. International Journal of Economic and Finance, 4(5), 73-84.

20. Poornima, S., \& Remesh, A. P. (2015). Construction of Optimal Portfolio Using Sharpe's Single Index Model-A Study with Preference to Banking \& IT Sector. International Journal of Applied Research, 1(13), 21-24.

21. Poornima, S., \& Remesh, A. P. (2016). A Study on Optimal Portfolio Construction Using Sharpes Single Index Model with Special Preference to Selected Sectors Listed in NSE. National Journal of Advanced Research, 2(3), 28-31.

22. Prasongko, D. (2019). Ada Aliran Dana Asing Rp195 T, BI: Investor Percaya RI. Retrieved from https://bisnis.tempo.co/read/1258608/ada-aliran-dana-asing-rp195-t-bi-investor-percaya-ri.

23. Pratama, L. A. (2019). Analisis Pembentukan Portofolio Saham Optimal Menggunakan Metode Single Index Model. Jurnal Ilmu Manajemen, 16(1), 48-60.

24. Saleh, T. (2020). Rapor LQ45 Sepekan: Ini Dia 5 Saham Terbaik Saat IHSG Jeblok!. https://www.cnbcindonesia.com/market/20200913223010-17-186488/rapor-lq45sepekan-ini-dia-5-saham-terbaik-saat-ihsg-jeblok

25. Sari, F. A., \& Nuzula, N. F. (2017). Pembentukan Portofolio Optimal dengan Model Indeks Tunggal: Studi Pada Perusahaan Property, Real Estate, and 
Nuiding Construction yang Tercatat di Bursa Efek Indonesia Periode 2013-2015. Jurnal Administrasi Bisnis, 45(1), 1-9.

26. Singh, S., \& Gautam, J. (2014). The Single Index Model \& The Construction of Optimal Portfolio: A Case of Banks Listed on NSE India. Risk Governance $\mathcal{E}$ Control: Financial Market E Institutions, 4(2), 110-115.

27. Tandelilin, E. (2017) Pasar Modal Manajemen Portofolio E Investasi. Yogyakarta: Kanisius.

28. Wahyuni, N. C. T., \& Darmayanti, N. P. A. (2019). Pembentukan Portofolio Optimal Berdasarkan Model Indeks Tunggal pada Saham Indeks IDX30 di BEI. E-Jurnal Manajemen, 8(6), 3814-3842.

29. Witiastuti, R. S. (2012). Analisis Kinerja Portofolio: Pengujian Single Index Model dan Naive Diversification. Jurnal Dinamika Manajemen, 3(2), 122-132. 